\title{
Det privilegerte stadsmusikantvesenet i Norge
}

En historisk-deskriptiv undersøkelse av embetets opprettelse, utvikling og fall

Arne Stakkeland

\section{Keywords}

Town-musician office, Bergen, Trondheim, Kristiansand, performers, composers, educators

\begin{abstract}
The task of the privileged town- musician office was to organize the towns secular music scene after the model of the handicraft guilds. The town musician institution was functioning in large parts of Europe. The system spread north and was introduced in Norwegian cities from the beginning of the $1600 \mathrm{~s}$, but under more arid conditions.

This article is based largely on studies of the town musician office in Bergen, Trondheim and Kristiansand. The study also provides the basis for discussions of town musicians as performers, composers, and educators, and their fight against competitive players.
\end{abstract}

\section{Innledning}

Ordet stadsmusikant kommer fra tysk, hvor "stadt" er det samme som stad eller nåværende by. En stadsmusikant, eller bymusikant, var per definisjon en privilegert yrkesmusiker som hadde monopol på levering av musikk i et avgrenset, administrativt område, dvs. byen og vanligvis et tilhørende landområde. Han hadde med andre ord enerett på levering av musikk til folk flest. Han spilte for alle både i byen og på landet, og nettopp dette gjorde ham til en viktig og sentral person i sin tid. Det har derfor undret meg at stadsmusikantene har fått en forholdsvis begrenset omtale i musikkhistorien. Nå har det riktignok kommet flere forskningsartikler og bøker som berører temaet i større og mindre grad, men noen samlet kronologisk fremstilling av disse musikerne finnes ikke fra noen norsk by. ${ }^{1}$

\section{Avgrensning}

Dersom en skulle få et helt korrekt bilde av stadsmusikantenes virksomhet og rolle i den norske musikkhistorien, måtte alle norske byers stadsmusikanthistorie med tilhørende arkivmateriale bli gjennomgått. Dette ville imidlertid kreve så mye tid at det arbeidsmessig måtte bli en nærmest uoverkommelig oppgave for en person alene. I min avhandling, Det privilegerte musikksystemet, ${ }^{2}$ valgte jeg derfor ut tre forskjellige norske byer med stadsmusikantembeter av forskjellig art og størrelse. Dette gjelder Kristiansand, som var

\footnotetext{
1 Dahlback (1956), Grinde (1971), Græsvold (1976), Hernes (1952), Huldt-Nystrøm (1977), Kortsen (1984), Michelsen (1987), Selvik (2005), Sivertsen (1975), Volle (1979), Vollsnes (1989 og 2001), Wiesener (1943).

2 Stakkeland, Arne (2001). Det privilegerte musikksystemet, Kristiansand, UiA nr. 35.
} 
handels- og garnisonsby, grunnlagt av Christian IV i 1641 (Steen 1941:45-64), handelsbyen Bergen, den viktigste hansabyen i hele Skandinavia, grunnlagt i 1070 av kong Olav Kyrre (Helle 1995), og Trondheim, med bispesete, erkebispesetet, kongens viktigste residensby fra 1031. Den sistnevnte var grunnlagt av kong Olav Tryggvason i år 997 og ble et kulturelt og kirkemusikalsk sentrum (Lundeby 1974:63-64). Altså tre byer med forskjellig alder og historie. Jeg har samlet alle stadsmusikantene i de tre byene i kronologisk rekkefølge og forsøkt å trenge dypere inn i deres liv og virke i tidsrommet 1600-1850. I historisk sammenheng er ikke dette en lang tidsepoke, men det er en viktig tid i norsk musikkhistorie.

Selve stadsmusikantideen kom til Norge fra Mellom-Europa via Tyskland og Danmark. På 1600-tallet fikk den grobunn i norske byer og ble etter hvert omformet til en norsk variant.

\section{Sentrale forskningsspørsmål}

Spørsmål som er naturlig å stille innenfor dette forskningsområdet, og som forsøkes å besvares i denne artikkelen, er:

1. Hva var innholdet i den norske varianten av stadsmusikantvesenet?

2. Hvordan gav de europeiske impulsene seg utslag i Norge?

3. Hvordan var stadsmusikantene som musikere, komponister og pedagoger, og hvordan førte de kampen mot konkurrerende spillemenn?

4. Hvorfor ble stadsmusikantembetet opprettet, og hvordan utviklet det seg?

5. Hva førte til monopolets oppløsning?

\section{Metode}

For å besvare disse spørsmålene har det vært viktig å oppspore og studere primærkilder, dvs. studier av originaldokumenter fra diverse Stats-, By- og Riksarkiv i norske, danske og tyske byer. I disse arkivale studiene har de kongelige konfirmasjonsbrevene for ansettelser av stadsmusikanter vært sentrale. Disse brevene, som er en kongelig bekreftelse på bestallingseller ansettelsesbrevene, er gjennomgått i kronologisk rekkefølge. Prosjektet har også medført gjennomgang av en forholdsvis stor mengde sekundærkilder som har gitt opplysninger av generell art, samt eksempler og fortellinger fra stadsmusikantenes dagligliv. Aviser fra denne tiden, samt diverse by- og kulturhistoriske bøker og skrifter er også gjennomgått systematisk. 
Når det gjelder notemateriell fra norske stadsmusikanter, finnes ikke så mye, men noe er funnet. ${ }^{3}$

\section{Hva var innholdet i den norske varianten av stadsmusikantvesenet?}

Under hele kildegranskingsprosessen har det vært en gjennomgående rød tråd å finne fortidens spor med tilsvarende informasjon. Jeg har forsøkt å finne ut av stadsmusikantenes funksjon, og belyse i hvilken grad likheter og forskjeller har vært avhengig av kulturelle og historiske fakta. Det har videre vært et mål å avklare om bytypene avspeiler ulikheter $\mathrm{i}$ stadsmusikantenes posisjon og status.

Hvordan var så den politiske situasjonen på denne tiden? Norge var i union med Danmark med felles konge, og forholdet disse landene imellom ble helt spesielt. 1520-30årene var preget av konflikter og krig. Unionskongen Christian III utmanøvrerte både norske biskoper og adelsmenn som prøvde å hevde seg mot ham. I 1636-37 trumfet han gjennom reformasjonen, og det norske riksrådet falt bort. Den såkalte norgesparagrafen i Christian IIIs håndfesting sa at Norge ikke lenger skulle være eget kongerike, men under Danmarks krone til evig tid.

Kong Fredrik III innførte eneveldet i tvillingrikene i 1660-1661. Årsaken til det var at alle krigene hadde stilt adelen som politisk bærende samfunnsgruppe i dårlig lys og borgerskapet forlangte større politisk innflytelse. En organisatorisk følge av dette var at Norge ble sterkere bundet til Danmark enn noen gang tidligere, en organisering som bestod helt frem til 1814.

Eneveldet gav sentraladministrasjonen og stadsmusikantembetet et administrativt enhetspreg i begge land, men det var også betydelige lokale forskjeller mellom norske og danske embeter både hva art og størrelse angikk. Virksomheten i Danmark-Norge bygget på en del generelle bestemmelser for dobbeltmonarkiet som fikk betydning både ved ansettelser $\mathrm{i}$ og utøvelsen av embetet. Norge måtte i utgangspunktet innordne seg de lover, regler og bestemmelser som til enhver tid gikk ut fra sentraladministrasjonen i København. Stadsmusikantvesenet fikk etter hvert en juridisk utforming som var grunnleggende for dens funksjon. Det var derfor naturlig å anta at kulturutviklingen i vårt land ble preget både av fellesskapet med Danmark og kontakten med Europa, også hva stadsmusikantinstitusjonen angikk.

Noteoversikt av følgende stadsmusikanter er ført opp bakerst i artikkelen: Saxild, O., Grose, M.E.,

Berlin, J.D., Schediwy, F.G. 
Stadsmusikantene var en forholdsvis liten gruppe embetsmenn som ble ansatt av byens øvrighet. De var yrkesmusikere med rettsvern, og hadde sin storhetstid i tiden 1500-1800. Denne perioden faller stort sett sammen med eneveldets utbredelse i Europa. Systemet hadde en del grunnleggende fellestrekk, som for eksempel byenes myndighet til ansettelse av en eller flere musikere til å utøve musikk i bestemte områder. De skulle utføre oppgaver byadministrasjonen påla dem, og fikk til gjengjeld privilegium på utøvelse av musikk i et bestemt omfang innenfor et geografisk område. Privilegiene omfattet byens borgere og de lavere sosiale lag, dvs. de personer som stod under byens jurisdiksjon. Disse borgerne var tvunget til å bruke stadsmusikantens musikere når de hadde behov for musikk. Privilegium på levering av musikk var en torn i øyet på andre musikere, siden det gav makt som både borgere og musikerkollegaer måtte bøye seg for dersom de ville unngå rettslige konsekvenser.

\section{Hvordan gav de europeiske impulsene seg utslag i Norge?}

De mange tyske og danske musikere som ble stadsmusikanter i norske byer, brakte med seg sin kultur, sitt repertoar og sin organisasjonsform og fikk på den måten stor påvirkning på det norske systemet.

Fra stadsmusikantvesenets historie i Europa vet vi at ulike kulturområder var avgrenset av forskjellige tradisjoner og praksis. Midt- og Syd-Tyskland, det nære middelhavsområdet og østersjøområdet er eksempler på slike kulturområder med en relativ musikk-kulturell enhet.

I 1991-1993 var jeg norsk representant i et nordisk samarbeidsprosjekt støttet av NOSH (Nordisk samarbeidsnemnd for humanistisk forskning) Prosjekttittelen var Østersjøområdet som musikklandskap. Målet var å skrive kulturområdets musikkhistorie, å finne et slags helhetssyn på musikklivets struktur, organisasjonsform og repertoar i dette området på 16001700-tallet. Musikkhistoriske likheter og overensstemmelser østersjølandene imellom synes å være tydelige, men ingen har forsøkt å forklare hvorfor. Prosjektgruppen bestod av forskere fra Sverige, Danmark, Finland, Tyskland og Norge. Østersjøområdet blir her betraktet som en egen kulturregion hvor de privilegerte stadsmusikantene innen musikkområdet utgjorde en viktig del av denne kulturregionen (Andersson 1994:73-85). En følge av hanseatenes handelsvirksomhet med så vel norske som østersjøiske byer var at musikkulturen også smittet over på enkelte norske byer, spesielt de med tysktilsatte stadsmusikanter. Norge ble med andre ord regnet med i Østersjøens musikklandskap selv om landet ikke grenset til Østersjøen, og tysk innflytelse på stadsmusikantvesenets begynnelse og utvikling i Norden går igjen i flere sammenhenger. I Østersjøområdet må en kunne si at nord-tysk innflytelse var så 
dominerende både innen de forskjellige byers musikktradisjon og ellers, at en i utgangspunktet nærmest kan snakke om et tysk fenomen som var kommet nordover til østersjøområdet (Schwab 1989:141-160). Kildene viser at byene i dette området i hansatiden i stor utstrekning hadde identiske organisasjonsformer for de musikerne som var opptatt $\mathrm{i}$ byog kirketjeneste. En møtte videre samme slags institusjoner og arbeidsoppgaver. Et tilnærmet ensartet forvaltnings- og privilegiesystem med utgangspunkt $\mathrm{i}$ tysk organisering og tradisjon var med på å muliggjøre blant annet datidens store musikermobilitet. I samme tidsrom brukte man også et beslektet musikalsk repertoar i disse byene. Også i orgelmusikken er det blitt hevdet at østersjøbyene hadde en egen felles orgelstil som ble kalt "den nordtyske", eller også omtales som "sjøfartsveldets orgelstil", et samlet miljø med Buxtehude som den fremste representant. Et fremtidig mål i forskningsgruppen var at arbeidet skulle munne ut i fire konkrete resultater:

* En kommentert musikalieutgave med musikk som belyste stadsmusikantenes ulike repertoar og virksomhet i østersjøområdet.

* En dokumentutgave som inneholdt lærling- og svennebrev, diverse fullmakter, takster og andre dokumenter av administrativ art.

* En bibliografi - en bibliografisk sammensetning av stadsmusikantvesenet i østersjøområdet.

* En database - et fremtidig stadsmusikantleksikon over musikere i østersjøområdet.

Dette er et krevende arbeid som ennå ikke er sluttført.

\section{Hvordan var stadsmusikantene som musikere, komponister og pedagoger, og hvordan førte de kampen mot konkurrerende spillemenn?}

Stadsmusikantene som musikereStadsmusikantene var forskjellige både som mennesker, administratorer og musikere. Embetsutviklingen kunne derfor variere alt etter hvem som hadde stillingen, men kongens makt og myndighet stod over dem alle.

Generelt kan en si at de norske stadsmusikantene kunne bestyre sitt embete uten virtuose ferdigheter. På den ene siden forteller kildene om dyktige musikere. Spørsmålet er da om hvilke muligheter de hadde til å utfolde seg faglig. Dansemusikken som alle stadsmusikantene betjente, kunne ikke gi de store virtuose utfordringene. Mulighetene hadde de i større byer i form av medvirkning til kirkemusikk, representativ musikk og konserter. 
Stadsmusikantens kunst betegnes ikke bare ut fra instrumentalvirtuositet, men like mye ut fra bredden i hans aktivitet. Dersom allsidighet legges til grunn i vurderingen av stadsmusikanten som kunstner, kan svært mange musikere komme positivt ut. Sett fra denne synsvinkel må en kunne si at stadsmusikantens profil var annerledes enn både organistens, kantorens, hoffmusikerens og militærmusikerens.

Hvor dyktige har egentlig disse musikerne vært? Ut fra de undersøkelser som er gjort, er der ingen tvil om at det har vært dyktige musikere blant de norske stadsmusikantene også. Stadsmusikant Johan Daniel Berlin i Trondheim var for eksempel regnet for å være en av de mest betydningsfulle stadsmusikantene i hele Norge, med betydelige musikkferdigheter (Gerber 1977:143-144). Han var også komponist og en viktig formidler av den musikalske utviklingen som hadde skjedd på kontinentet. Som representant for dette nye må en kunne si at Berlin medvirket til at både by og land ble kjent med de musikalske strømninger som spredde seg fra land til land på hans tid, men det gjaldt også flere av hans kollegaer.

Ferdinand Schediwy i Bergen, den første sanglæreren til Edvard Grieg (Reznicek 1975), var også regnet for å være en dyktig fiolinist, domorganist, dirigent og konsertgiver. Johan Chr. Schlossbauer, som også virket i Bergen, var regnet for å være en ypperlig fiolinist (Stakkeland 2011:62). I Kristiansand var Michael Ehregott Grose konsertmester i Det Musikalske Selskab. Han var dessuten både organist og komponist. Sin musikalske opplæring hadde han fått av sin far, Johan Michael, som var en flittig elev av Johan Sebastian Bach (Dobitschen 1949:104-105). Ferdinand August Rojahn opptrådte som fiolinist i "Theateret". Han var regnet for å være en dyktig utøver og dirigent. Den største innsatsen gjorde han på sangens område, både som dirigent for flere kor og for opprettelsen av en sangskole for "ukonfirmerede Børn af begge Kjøn over 7 Aar.,"

\section{Stadsmusikantene som komponister}

Stadsmusikantene var først og fremst utøvende musikere. Det var ingen krav om at de skulle komponere. Når noen prøvde seg som komponister, var det selvsagt med på å styrke deres posisjon og anseelse. Når en kan si at det er forholdsvis lite musikk som er overlevert fra norske stadsmusikanter, gjelder dette også for andre land i Europa. Noen norske komponister blant stadsmusikantene er allerede nevnt, men siden det kun gjelder de tre norske embetene av

Christianssands Stiftsavis, nr. 34, 1847.

Rojahn, Ferdinand: "Historisk oversikt over Musikforholdene i Kristiansand ", Bilag til Christianssands

Tidende, nr. 196, 1892. 
i alt 15 i 1787, dvs. litt over $20 \%$, blir det vanskelig å si om denne musikken er representativ for alle byene i Norge.

Fungerende stadsmusikant Otto Saxild i Kristiansand (1788-1795) har etterlatt seg en vals som er skrevet i 1791 (1792). Denne er interessant da valsen må ha vært en av de første som ble komponert $\mathrm{i}$ vårt land. En kjenner til at valsen kom til Norge rett før år $1800 \mathrm{og}$ ble populær her tidligere enn i mange andre land. Siden Saxild også var danselærer, har han da laget en nymotens dans etter tidens mønster med åtte takters repriser. Jeg skal ikke gå inn på noen analyse av komposisjonen, men kun nevne at Saxild ikke viser seg som noen stor komponist. Komposisjonen som helhet må mer betraktes som et dilettantisk produkt, men han har nok gjort bruk av den i sin danseopplæring. Hans forgjenger Michael Ehregott Grose (1787-1788) har derimot etterlatt seg flere komposisjoner som bekrefter at han hadde en forholdsvis omfattende produksjon å vise til. Han hadde bedre tak på komposisjonsteknikken enn Saxild, men Grose hadde nok fått veiledning av sin far. En må gå ut fra at han kjente til musikk både fra eldre og samtidige, toneangivende komponister. Han reiste også en del og har trolig fått mange impulser som han kunne formidle videre til Kristiansand, der han både var orkesteranfører i Det musikalske selskab og konstituert stadsmusikant. Det finnes noter av Grose, både en klaversonate, lette klaverstykker, lieder, kantater og sanger. Heller ikke Grose kan karakteriseres som noen kompositorisk mester.

Den tidligste av stadsmusikantkomponistene jeg har funnet noter av, er Johan Daniel Berlin, som var stadsmusikant i Trondheim i tiden 1737-1767. Han var en dyktig og produktiv komponist som skrev konserter, symfonier, kantater, cembalosonater, danser m.m. Dessverre er mye av denne musikken gått tapt, og kun det som er oppført bakerst i denne artikkelen, er bevart. Berlin har trolig vært mest aktiv som komponist i en periode som var preget av overgangen mellom barokk og wienerklassisisme. I denne overgangsperioden mellom gamle og nye stilidealer fikk Johan Daniel Berlins komposisjoner sin form. Det må nødvendigvis ha gått litt tid for å forlate det gamle til fordel for nye tanker og ideer. I denne prosessen har det lett for å bli eksperimentering og en blanding av begge deler. Dette er da også Berlin et offer for. Det finnes for det første barokke sider ved hans musikk både når det gjelder terrassedynamikk og basso continuo. Fra en annen side er melodiføringen i komposisjonene som regel alltid i overstemmen. Han har normalt en forholdsvis enkel melodikk med treklangbrytninger. I fiolinkonserten er for eksempel melodikkens korte motiver ofte basert på treklanger som repeteres med visse mellomrom. Satsen er dessuten homofon. I cembalostykkene finner en også albertibass i venstre hånd. Alt dette peker i retning av den galante stil. En kan dermed konstatere at Berlins komposisjoner har trekk av 
dette nye stilidealet samtidig som han har beholdt noen av senbarokkens elementer. Berlin er en komponist på et betydelig høyere nivå enn de tidligere nevnte.

Den stadsmusikanten som har etterlatt seg flest komposisjoner, er nok Ferdinand Giovanni Schediwy, som var en av de siste konstituerte stadsmusikantene i Bergen (18371838). Som stadsmusikant, organist, komponist, sanglærer, dirigent og dyktig fiolinist ble han byens "altmuligmann" i faget. Hans allsidighet avspeiler seg også i hans komposisjoner både til bruk i kirken, på scenen, til skolesang/barnesang, musikk til underholdning, sanger for mannskor, musikk til dans, etc. Det meste av dette er skrevet etter at stadsmusikantembetet ble nedlagt, og er følgelig ikke gjennomgått, mens noe er udatert. Noe faller imidlertid innenfor hans stadsmusikanttid, og det er grunn for å tro at mye av hans musikk var av en høyere standard enn det som er gjennomgått i denne sammenhengen.

\section{Stadsmusikantene som pedagoger}

Når en stadsmusikant ble tilsatt, forventet byens magistrat at han skulle holde et nødvendig antall svenner og lærlinger. Stadsmusikantene fremhevet lærlingutdannelsen som en kvalifikasjon. Det var den eneste formaliserte musikkutdannelsen før konservatorienes tid, og også latinskolene og private fikk nyte godt av stadsmusikantens pedagogiske virksomhet.

Før en person kunne begynne sin læretid, ble det opprettet en lærekontrakt mellom lærlingens far/foresatte og stadsmusikanten. Lærlingen ble deretter plassert i stadsmusikantens hus for å utdannes i faget i et visst antall år. Opplæringen ble som regel avsluttet med et svennebrev, og han kunne da kalles svenn. Et eksempel på en slik lærekontrakt finnes fra 1714 mellom Bendix Coch i Trondheim og en lærling ved navn Lars Larsen Baer. Kontrakten, som er underskrevet av lærlingens mor, lærlingen selv og to kausjonister, bekrefter en læretid på 3 år $^{6}$. Det litt spesielle her er at læretiden kun er 3 år, mens det vanlige var fra 5 til 6 år. Kanskje har lærlingen her hatt ekstra gode forkunnskaper som tilsa at han gikk i lære kortere tid enn vanlig.

Innholdet i stadsmusikantens pedagogiske virksomhet ut over å gi opplæring på flere instrumenter, kjenner en i liten grad til. Hos enkelte stadsmusikanter finnes en del lærebøker som kan gi oss en dokumentasjon på hva stadsmusikanter var i besittelse av. Johan Daniel Berlin hadde blant annet en fløyteskole av J. Quants, fiolinskole av Leopold Mozart og klaverskole av Carl Ph.E. Bach. Han hadde også flere lærebøker i teorifag, men de var nok for vanskelige for bruk til nybegynnere. ${ }^{7}$ En god del tips kunne han nok likevel finne til bruk i

Trondhjems pantebog 1714. Brodahl 1, s. 312-313.

Auksjonskatalogen med "Fortegnelsen over adskillige Mathematiske og Musikalske Instrumenter, samt 
undervisningen, men det krevde både pedagogisk og metodisk innsikt for å overføre lærdommen til sine elever. Det finnes ingen dokumentasjon på stadsmusikantens metodikk. Det han egentlig trengte i den sammenheng, var en lærebok i elementær musikklære og instrumentkunnskap, men slike bøker fantes ikke før på slutten av 1700-tallet. Det var derfor ingen tilfeldighet at nettopp stadsmusikantene Berlin i Trondheim og Berg i Kristiansand ble forfattere av hver sin lærebok for bruk i begynneropplæringen. Disse bøkene kunne lette den teoretiske delen betraktelig og være med på å systematisere opplæringen. Det er her snakk om de to eneste lærebøker av stadsmusikanter i Skandinavia. Stadsmusikant J.D. Berlin skrev den første boken, som kom ut i Trondheim i 1744 med tittelen Musicaliske Elementer eller Inleedning til Forstand på De første Ting udi Musiquen. Ifølge ham selv skulle boken være "Til oplysning for dem som har Lyst, at faae, Forstand paa det Musicaliske Væsen, og betragte Guds Gave"8. Målgruppen for bokprosjektet er nybegynnere og interesserte musikkamatører for bedre å forstå "det Musicalske Væsen" (§ 22 i Fortalen). Han tenker også på datidens pedagoger som skal lære fra seg, og understreker at de bør vite hva de gjør.

38 år senere kom den neste læreboken, av stadsmusikant Lorentz Nicolai Berg i Kristiansand. Boken Den første Prøve for Begyndere udi Instrumental-Kunsten forelå i 1782. Forfatteren sier selv at han har "... søgt at bekomme en simpel og tydelig Musicalsk A.B.C. til Lattelse, når man informerer udi Musiqven, ...". ${ }^{9}$ Læreboken må altså oppfattes som en veiledning for datiden musikkpedagoger på begynnerstadiet. Berg stiller krav til pedagogen, som selv må forstå musikken og undervise i "Nodernes Egenskaber og Ambitus". Berge har ikke noe fast opplegg for undervisningen sin og har heller ingen sans for systematikk. Han blir ofte opptatt av uvesentlige ting og gjør til tider naive sidesprang. Jeg kan ikke gå nærmere inn på detaljer i denne sammenheng, men viser til min avhandling Det privilegerte musikksystemet.

\section{Kampen mot konkurrerende spillemenn}

Det er et faktum at det også i Norge var to slags musikkliv: det privilegerte og det uprivilegerte. På den ene siden stod det offisielle og profesjonelle stadsmusikantvesenet, og på den andre siden var det uprivilegerte, uorganiserte musikklivet. Disse to partene lå i stadig konflikt med hverandre. Det er derfor naturlig å spørre om stridighetene mot konkurrerende

Bøger i adskillige Videnskaber som først i tilkommende Aar 1788 blive bortsolgte ved Auction i afg. Overbrannmester Berlins Huus her i byen”. Ett eksemplar av denne fortegnelsen, hvor siste side mangler, er bevart og finnes på Nasjonalbiblioteket i Oslo.

Sitat fra "Fortalen", § 21 i læreboken Musicaliske Elementer.

Sitat fra "Fortalen" i læreboken Den første prøve... 
spillemenn fikk noen betydning for utviklingen av privilegiene og/eller kvalitetsnivået på utøvelsen av musikken eller musikkvalget. Hvordan var forholdet til lokale spillemenn? Mange foretrakk å bruke uprivilegerte musikere til sine arrangementer. Det kunne være bygdespillemenn, amatører eller militærmusikere. Dersom stadsmusikanten oppdaget dem, kunne saken bli anmeldt med etterfølgende rettssak. De som spilte ulovlig, gikk under navnet fuskere. Det ville føre for langt å gå inn på alle disse problemstillingene i denne sammenhengen, men jeg vil her ta for meg noen områder og forsøke å se dem i historisk perspektiv.

Siden stadsmusikanten selv måtte anmelde fuskerne, brukte han også mye tid på å finne musikerne som brøt hans privilegier. Dette gjelder for alle byene, men spesielt Trondheim førte en hard og vedvarende kamp mot fuskerne. Stadsmusikant Krigsmand i Trondheim opplyste for eksempel til stiftamtmannen i 1711 at han dette året hadde brukt dobbelt så mye penger som han tjente, i kampen mot fuskerne. ${ }^{10}$

Privilegiesystemets idé om at musikkutøvelse skulle forbeholdes noen få, var i utgangspunktet problemskapende. Konflikten var liksom innebygget i systemet mellom profesjonelle og ikke-profesjonelle utøvere. Dette motsetningsforholdet avspeiler seg allerede ved tilsettingen i Bergen i 1620, hvor de privilegerte musikerne ble gitt mulighet til å klage ulovlig musisering inn for byfogden. Inntrengerne skulle miste instrumentene og forvises fra byen.

En kan skille mellom to typer fuskere: de bofaste og de tilreisende. De bofaste hadde som ordet sier, sitt bosted i nærområdet og kjente følgelig til stadsmusikantens privilegier. De lokale spillemenn spilte gjerne billigere og kjente som regel til lokalbefolkningens dansetradisjoner. Det var nok disse som skaffet stadsmusikanten størst konkurranse. De var også kjente av rekvirentene. De tilreisende eller mobile spillemennene kunne være soldater, tiggere eller arbeidssøkende. Disse var ikke så godt orientert om instrumentistens privilegieområde, men de tok sjansen på å spille når anledningen bød seg. Den ulovlige konkurransen var vanskelig å få stoppet da den som regel hadde støtte av lokalbefolkningen. Gammel praksis stod mot privilegiene, og stadsmusikantene var ofte fortvilet for situasjonen.

Byens magistrat og hans folk fulgte opp når fuskerne ble tatt, men de tok ikke selv noe initiativ $\mathrm{i}$ form av omorganisering eller intensivering av jakten på ulovlighetene. Kongelige reskripter og reglement var tydeligvis ikke nok for noen av byene. Det var da opp til 
stadsmusikantene selv å avgjøre hvor mye tid og krefter de ville bruke i denne kampen. Problemet ble ikke løst i hele stadsmusikantperioden.

\section{Hvorfor ble stadsmusikantembetet opprettet, og hvordan utviklet det seg?}

Kildene omtaler ofte stadsmusikantstillingene som embeter og innehaverne som embetsmenn med visse privilegier. Det er viktig å være klar over at privilegiene spilte en stor rolle i middelalderen. Privilegier kunne til tider ha karakter av unntak både fra lov og særrettigheter, eller det hadde ikke lovhjemmel i det hele tatt. Den eneveldige kongen hadde dessuten mulighet til å gi privilegier til hvem han ønsket. At privilegiene skulle forbeholdes noen få, var i seg selv udemokratisk. Vår tids ideal om mest mulig likhet for loven var tydeligvis ukjent for datidens tankegang. Det ble motsigelser i systemet som folk måtte leve med (Jespersen 1989:177).

Stadsmusikantene som institusjon har vært i funksjon mer og mindre i store deler av Europa. Den oppstod ikke plutselig, men utviklingen gikk fra omvandrende spillemenn, via fast tilsatte spillemenn eller tårnmenn til kongelig tilsatte stadsmusikanter med privilegier og tilsvarende rettigheter og plikter. Denne veien har vært relativt lang, og utviklingen har gått trinnvis.

\section{Utvikling av stadsmusikantembetet}

En må tilbake til middelalderen for å finne de første spor av spillemenn. De fleste musikantene som hadde musikk som levebrød før stadsmusikantenes tid, hørte til gruppen omvandrende spillemenn, ofte kalt sjonglører, trubadurer, truverer eller også minnesangere. Disse menneskene førte et omflakkende liv uten fast bosted. De drev også med forskjellige former for artisteri, gjøgleri eller spilte teater. Deres sosiale og rettslige status var tvilsom, og de ble ofte betraktet som uærlige både av byens borgere, den verdslige øvrighet og kirken (Zak 1979:279-291; Budde 1842:48ff.). De omvandrende spillemenn kunne ikke gjøre krav på arv overfor ærlige foreldre eller opptas i håndverkerlaug. De ble nektet kirkens sakrament og begravelse i viet jord, da kirken betraktet dem som rester av hedenskapen, ja til og med redskap for djevelen. Synet var imidlertid ikke absolutt. Ordet spillemann var et svært vidt begrep som omfattet andre former for opptrinn enn musikk, et samlebegrep for farende folk av forskjellig klasse. Kirkens holdning til disse menneskene var riktignok varierende, og det samme kan sies om rettsvernet i forskjellige land i Europa.

I løpet av middelalderen skjedde imidlertid store forandringer, da kirken ble mer liberal overfor instrumentalmusikken. Fra å være fordømt av kirken kunne de slutte seg 
sammen i broderskap og dermed bli beskyttet av den samme kirken. Det finnes flere eksempler på det fra europeiske byer (Wien 1288, Paris 1321, Lübeck i første del av 1300tallet). Dette var et viktig steg i retning av å bli akseptert og innpasset i samfunnet og følgelig komme bort fra å bli stemplet som uærlige og rettsløse (Koudal 2000:64).

En annen måte å bli akseptert på var å få seg en stilling hos en makthavende fyrste eller til og med få ansettelse i en by. Da bysamfunnene vokste frem, ble det nemlig bruk for deres musikalske ferdigheter i forskjellige samfunnsmessige sammenhenger. Det kunne være som tårnvektere til å blåse diverse signaler og annen vakttjeneste eller tårnblåsere som utførte sine tjenester på blåseinstrumentene trompet, horn og skalmeie. Disse personene ble etter hvert helt nødvendige for byen og følgelig fast tilsatte. De inngikk da kontrakt med byrådet og avla ed på at de skulle tjene byen og borgerne på beste måte. Det finnes eksempler på slike "Türmereid" blant annet fra Kiel på 1500-tallet (Haensel 1970:109). Det finnes også eksempler på tilsatte tårnblåsere i England på 1200-tallet under betegnelsen "waits" (Langwill 1952:170-83). En har også flere eksempler fra Tyskland på samme tid, men her under navnet "Stadtzinkenist" eller "Thürmer" og "Hausmann" dersom de bodde i tårnet (Mendel 1878:395). Eksempler finnes også både i Sverige (Norlind 1940:50) og Danmark (Schiörring 1977:281).

\section{Leikare og skalder}

I gammel norsk-islandsk litteratur kan en lese om "leikari", som levde av å underholde, i motsetning til datidens skalder (Seip og Wallén 1965:462-467; Schiörring 1977-78:65-80; Olrik 1886:74-84/265-266; Norlind 1940:29-52). Den kjente islandske høvdingen Snorre Sturlason omtalte kongen, Håkon Håkonsson, på 1200-tallet, som tvilsom fordi han hadde kontakt med omvandrende leikare/gjøglere. Tilsvarende opplysninger finnes også fra Sverige og Danmark, nemlig forakt for leikare i motsetning til skaldene. Leikare i Norden hadde heller ingen rettsbeskyttelse og kan i så måte sammenlignes med spillemennene i Europa. Etter 1500-tallet ble ordet leikare ofte erstattet med spillemenn.

I Magnus Lagabøtes bylov fra 1276 hører en om et tredobbelt vaktsystem med horn og klokke som varselsignal (Keyser og Munch 1848:242). Noen byer hadde også brukt trommeslagere til oppgaver i militæret eller ved representasjon. I middelalderkunsten ble leikare ofte avbildet med sine instrumenter for eksempel i kirkens kalkmalerier og i mer folkelige fremstillinger av bibelhistorien. Skulpturen i Nidarosdomen av en musiker som spiller på et strykeinstrument, er datert til 1100-tallet. 


\section{Tårnblåsere}

I enkelte byer ble også tårnblåserne brukt til underholdning og dans for borgerne. Deres oppgaver ble stadig flere, og kravene til deres prestasjoner større. $\AA$ kombinere tårnblåserfunksjonen med byenes stadig voksende behov for underholdning og medvirkning ved forskjellige anledninger var ikke alltid like lett. Byens magistrat så også en fare i denne utviklingen og understreket at tårnblåserne ikke måtte forlate tårnet uten hans tillatelse. De var faktisk byenes sikkerhetsvakter, og konsekvensene av å ikke ha dem på plass kunne være katastrofale. Tårnblåsernes prestasjoner hadde dessuten sin begrensning, og kravet til mer skolerte musikere var så absolutt til stede. Det neste trinn var da å ansette faste musikere med rettigheter og plikter, og disse fikk tittelen stadsmusikanter.

\section{Larm og musikk}

De middelalderske byene brukte også sine musikere til å gi byene ære og pryd (Zak 1979; Schwab 1982:28-33/51-58). Det var også en vanlig middelaldersk oppfatning at det fulgte en særlig verdighet med stor lydstyrke. Larm og musikk uttrykte rettsmessig makt, anseelse og anerkjennelse. Lydstyrken hadde i middelalderen sin egen verdi. Den høye akustiske ytringen spilte med andre ord en viktig rolle både i musikalske og utenom-musikalske former. Akklamasjon var for eksempel et gammelt uttrykk for enighet. Jo høyere den var, jo større betydning fikk den. I den tiden var oppfatningen blant folk flest at Guds Ånd ytret seg høylytt, og overmenneskelig lyd var tegn på Guds inspirasjon. Larmen i krig skulle simulere en større hærstyrke enn den virkelige. Den voldsomme lyden av horn, trompeter og trommer understøttet den menneskelige stemme og var uttrykk for styrke. I rettsvesenet ble også musikk og larm brukt både til bekjentgjørelse og avstraffelse av rettsforbrytere. Dette forstørret skammen samtidig som saken fikk en rettslig anerkjennelse.

Borgerforsamlinger ble innkalt med klokker, horn eller trompeter, og musikk ble også brukt ved bekjentgjørelser av traktater, kommunale vedtekter etc. på torvet, kirkebakken eller rådhusplassen (Schwab 1997). Musikken ble med andre ord satt inn i rettslivet for å annonsere at alt gikk riktig for seg. Det er vanskelig å finne eksempler fra Norden på at musikken ble tillagt en tilsvarende funksjon og betydning, med unntak av bryllupsmusikken (Troels-Lund 1939:396 ff.). Trommen var det instrumentet vanlige folk likte best. Det var en bekreftelse på ekteskapets gyldighet. 


\section{Hvordan var så forholdene i norske byer?}

Omkring 1350 gjorde hansaene sin entré i norske byer og preget handelen et par hundre år fremover. Den store båttrafikken gjorde det forholdsvis lett å reise til norske byer, både fra inn- og utland, og spesielt til Bergen, som følgelig fikk stor pågang av folk som søkte borgerskap. Blant disse var også en del spillemenn (Nicolaysen 1878). Ludvig Holberg gir sine bysbarn følgende omtale i sine Memoirer fra 1744:

Bergen i Norge, hvor jeg er født, kan lignes med Noce Ark, hvorudi der ere alle slags Creaturer, Thi Folk fra alle Verdens Kanter strømmer did hen, scette sig der ned, og forene sig med Indbyggerne (Holberg 1943:2).

Byen hadde permanente forbindelser både til Hamburg, Lübeck og flere hansabyer i østersjøområdet (Grimberg 1960:48). En undersøkelse gjort ved Statsarkivet i Bergen viser at i perioden 1613-1620 hadde 49,5 prosent av Bergens befolkning flyttet til byen fra utenfor landets grenser. Av disse hadde 22,7 prosent fødested i Tyskland (Nedrebø 1992). En stor del av stadsmusikantene som ble ansatt i Bergen, var fra Tyskland eller av tysk opphav. Det var Bergen som naturlig nok var først ute med å ansette stadsmusikanter, to samtidige, så tidlig som i 1620. ${ }^{11}$ Men allerede før den tid hadde den enes far (Luchas Jochumssøn) hatt privilegier på å være byens musiker med ansettelse en eller annen gang mellom 1591 og 1620 .

I tiden 1620-1848 (228 år) hadde Bergen tilsatt 22 musikere i stadsmusikantstillinger. Trondheim hadde ni tilsatte stadsmusikanter i tiden 1673-1845 (171 år), mens Kristiansand hadde 13 tilsatte fra 1680 til 1853 (173 år). Ut fra dette kan man si at stadsmusikerembedet i Norge varte fra ca. 1600-1853. I Kristiansand virket også den siste stadsmusikanten i Norge. Alle tre byene hadde en forholdsvis stor prosent tyske musikere i stillingene, men det var flest av dem i Bergen.

På 1600-tallet hadde Norge stadsmusikanter i 9 byer med tilhørende distrikter og landområder. I embeter som omfattet flere byer, fikk hver enkelt by etter hvert sin egen stadsmusikant, og i 1787 hadde i alt 15 norske byer egen stadsmusikant. Dermed var hele landet dekket, også Nord-Norge, som var en del av Trondheim stift. Dette ble senere innskrenket til kun å dekke byen og de nærmeste landområder rundt.

11 Danske Kancelli, Norske Registre, 1637-1642, folie 215b-217b, Riksarkivet i Oslo. 
Deres faglige nivå varierte, og den regionale musikkulturen fikk i betydelig grad den profil musikeren selv og hans elever stod for. Hittil er de blitt plassert i den mer anonyme delen av musikkhistorien. De var imidlertid en viktig del av samfunnsstrukturen.

Stadsmusikantene måtte innordne seg skikk og bruk, offentlig orden og god oppførsel. De måtte ta hensyn til andre grupper i samfunnet som også hadde spilleprivilegier. Det gjaldt både organister, latinskole-elever og hautboister, som var en generell yrkesbetegnelse for en militærmusiker. I "Det Trondhjemske Nationale Regimente" ble det i 1693 engasjert militærmusikere fra Hamburg som "Kunstpfeiffer, Schalmejblæser og Dulcianblæser". Skalmeien ble etter hvert avløst av oboen, som hadde finere klang. Tittelen som militær skalmeieblåser ble i Trondheim Bytingsprotokoll fra 1701 erstattet med "Hoboeblæsere" (Huldt-Nystrøm 1977:130).

I Sverige fikk oboistene navnet "Hautboist", mens oboblåserne i dansk-norsk sammenheng blir omtalt som houtboister eller hoboister. I norsk sammenheng kunne disse musikerne bli plagsomme når de tok spilleoppdrag fra stadsmusikanten.

\section{Hvordan ble en musiker stadsmusikant?}

I et kongelig åpent brev av 3. august 1670 står følgende:

At alle Oberformyndere, Underfogder, Vagtmestere, Havnefogder, Maalere, Veiere, Vragere, Bedemænd, Instrumentister, og alle andre Byernes Betjente, af slig eller ringeste Concideration, maae af de udi enhver Kjøbstæd forordnede Borgermestere, og af Præsidenten tilligemed Borgermesteren, hvor Præsident ere, i Riget Danmark efter Fornødenhed antages og forordnes, paa Kongens videre allernaadigste Confirmation, til hvilken Ende de under Ansvar have den Abstalt at giøre, at de Personer vorde til slike Bestillinger befordret, som dertil dygtige ere (Fogtman 1786-1854 nr. 2:9).

Det går her klart frem at borgermesteren kunne velge stadsmusikant, men kongen skulle godkjenne eller konfirmere valget. Med den prosedyren ble kongen til enhver tid informert om de forskjellige stadsmusikantembeter. Han hadde også mulighet til selv å påvirke valget, noe han også benyttet seg av, spesielt i København.

En tilsvarende ordning ble utstedt for Norge ved et reskript til stattholderen av 31. juli 1670 ang. hvilke Betjenter udi Kjøbstcederne som Presidenten eller Borgermesteren maa beskikke for Norge. Stattholderen ble her overlatt tilsynet med reskriptet, som sa at 
kjøpstedenes president eller borgermester i Norge blant annet skulle "forordne og beskikke instrumentister" (Wessel-Berg 1814-47:58). Reskriptet forenklet alle lokale utnevnelser, og mange norske byer benyttet seg av denne muligheten. Det var også her vanlig at bestallingen eller ansettelsen fikk kongelig bekreftelse eller konfirmasjon, men det var ingen plikt. De fleste ville gjerne ha kongens bekreftelse og hans underskrift med en skrift som i seg selv var et kunstverk.

Sett fra den eneveldige kongens side var dette enda et eksempel på hans ønske om større kontroll med stadig flere områder av samfunnslivet. De kongelige musikerne ble imidlertid favorisert, dvs. hautboistene og medlemmer av Det kongelige Kapel (orkester).

\section{Stadsmusikantstillingen og de mange reskripter}

Et reskript av 1711 fastslo at hoffet, militæret og universitetene kunne gjøre bruk av hvilke musikere de ville. Stadsmusikanten fikk enerett på spilling i bryllup der bruden var av borgerstand og bryllupsfesten stod i borgerhus. Dersom kun en av disse betingelsene var til stede, kunne houtboistene spille (Nielsen 1872-1887 nr. 8). Reskriptet førte til mange konfrontasjoner mellom stadsmusikanten og houtboistene (Christensen 1916:328-335).

Den 14. juni 1780 kom enda et kongelig reskript som gav musikere fra Det Kongelige Kapel førsteretten til ledige stadsmusikantembeter i tvillingrikene. Hensikten med dette var å heve det musikalske nivået i kjøpstedene som var "maadelig og paa de fleeste Steder besynderlig slet" (Fogtman 1786:302). I praksis betydde dette at når et embete ble ledig, skulle byens magistrat straks sende melding om dette til overhoffmarskalken sammen med en beregning på mulig inntekt i stillingen. Han kunne da foreslå to eller tre av kapellets musikere som magistraten selv kunne velge blant. Dersom ingen av disse var interessert eller kongen ikke ville unnvære noen av de foreslåtte kandidatene, kunne magistraten ansette fritt hvem han ville. Begge disse reskriptene kan oppfattes som om kongen ville pensjonere musikere fra sin tjeneste, og gjerne slik at de ble tildelt en stadsmusikantstilling som takk for lang og tro tjeneste i hær, flåte eller kapellorkester. Kvalifikasjonene til utøverne kom altså ikke i første rekke slik hensikten var. Dersom en magistrat ikke var interessert i kongens egne musikere, gav han gjerne en beskrivelse av byens embete som ytterst vanskelig rent økonomisk. Resultatet ble gjerne at ingen fra Det Kongelige Kapel var interessert i en stilling som gav så liten inntekt. Det skjedde for eksempel i Kristiansand da magistraten i byen sendte overhoffmarskalk Numsen et brev hvor han berettet at stadsmusikant Berg var død, og samtidig beskrev stillingsinntekten i byen på en bedrøvelig måte. Maksimal årsinntekt ble satt 
til 150-200 Rdlr. Magistraten oppnådde hensikten. Ingen i Det Kongelige Kapel var interessert $\mathrm{i}$ en stilling med så lav inntekt. ${ }^{12}$

Det kom mange slike kongelige reskripter, resolusjoner og lover som gjaldt stadsmusikantembetet i tvillingrikene. Jeg skal ikke gå inn på alle, men må nevne loven om "indfødsretten" av 29. januar 1776, som sa at samtlige embeter for fremtiden skulle forbeholdes dem som var født i Danmark-Norge, inklusive hertugdømmene Schleswig og Holstein (Feldbæk 1991:182-218). Loven gjaldt også stadsmusikantembeter, og konsekvensen var blant annet at det i utgangspunktet ble svært vanskelig for utlendinger å få slike stillinger. Kongen kunne imidlertid gi dispensasjon, noe han også gjorde når det ikke fantes kvalifiserte søkere innenfor landets grenser.

\section{Embetets eksistens}

Den kongelige resolusjonen som fikk stor betydning for embetets fortsatte eksistens, var fra 25. april 1800, en bestemmelse om sammenslåing av organist- og stadsmusikantstilling når anledningen bød seg. Den sa også at musikknæringen på landet skulle frigis. ${ }^{13}$ Resolusjonen gjaldt både for Danmark og Norge, men praksisen ble forskjellig $\mathrm{i}$ de to land. Sammenslåingen av de to embetene var et forsøk på å skaffe musikerne et levebrød. Behovet for stadsmusikantens tjenester ble på slutten av 1700-tallet redusert, og kirkemusikken hadde fătt mindre betydning enn tidligere. Tidene hadde forandret seg, og fuskerne ytte stadig stadsmusikantene større konkurranse. Frigivelsen av monopolet på landet gav for mange stadsmusikanter betydelige reduksjoner i inntekten.

En bestemmelse som alltid fikk konsekvenser for stadsmusikanten, var forordningene om "sørgeår" med "Forbud paa Spil og Leeg i Kirckerne og uden for". ${ }^{14}$ Sørgetiden kunne vare opp til et helt år og gjaldt ved dødsfall av konger, dronninger, enkedronninger, prinser og prinsesser. Inntekter for medvirkning i kirken, ved brylluper og andre festlige anledninger av privat karakter falt bort, med de økonomiske følger det fikk.

Byene måtte ha en størrelse og en oppgavemengde som medførte at stadsmusikantene kunne skaffe seg den nødvendige inntekt. Dersom ikke dette gav nok penger i kassa, hadde de også andre inntektsgivende gjøremål utenom det rent musikalske. Her var musikerne i Kristiansand svært kreative. Fungerende stadsmusikant og organist Otto Saxild hadde

\footnotetext{
12 Magistratens Copibog for Kristiansand, nr. 25, s. 685-686.

Kongelige Rescripter, Resolutioner og Collegial-breve, bd. 4, 1797-1813, 29. mai 1800, Christiania 1845 .

14 Kong Christian den Femtes Forordninger og Aabne Breve 1699-1700, København uten årstall, s. 4f.
} 
danseskole i Kristiansand og Mandal. ${ }^{15}$ I 1787 averterer han i avisen Christiansandske UgeBlade at han i tillegg til danseundervisning også gir "Informasjon i Claveer, Violin, Latin, Græsk og andre til de Kongelige Kiøbenhavnske Academie forordnede Videnskaber”. En av hans forgjengere, Lorentz Berg, drev vertshus med skjenkestue og gav små konserter . Han var også pantelåner, solgte strenger og instrumenter. ${ }^{16}$ Alle disse gjøremål var for å bedre økonomien totalt.

I Bergen fikk stadsmusikantene fra begynnelsen kun betaling for de tjenester de utførte, og stadsmusikant Lucas Jocobssøn sendte allerede i 1661 brev til kongen der han ber om 3 Rigsdaler i lønn fra byen, slik det var vanlig i andre byer og kjøpsteder i kongeriket. ${ }^{17}$ Noe svar på henvendelsen er ikke funnet. I 1748 ble det imidlertid innvilget fast lønn til stadsmusikant Christian Bonny på 60 Rigsdaler årlig fra Bergens tre hovedkirker. ${ }^{18} \mathrm{I}$ andre norske byer fikk de fast lønn fordelt mellom kirken og byen. Byene var forskjellige og forholdene tilsvarende. Det er ellers vanskelig å sammenligne stadsmusikantenes faste lønn i samme by og byene imellom, da inntektsforholdet til stillingene varierte med oppgaver, bystørrelse og posisjon. Det en med sikkerhet vet, er størrelsen på den faste årslønnen de tre undersøkte norske byene betalte til sine stadsmusikanter for plikter i kirken og byen, og det viser følgende:

\author{
Bergen: $\quad 60$ Rigsdaler fra kirkene ${ }^{19}$ \\ Trondheim: 50 Rigsdaler fra byen ${ }^{20}$ \\ Kristiansand: 80 Rigsdaler fra byen og kirken (en periode 100 Rigsdaler) ${ }^{21}$
}

I tillegg til den faste lønnen fikk stadsmusikanter også inntekt for underholdning hos private borgere. Det var monopolet på oppvartning med musikk i forskjellige borgerlige anledninger som skapte de største problemene. Fuskerne var særlig aktive i Trondheim.

Embetene gikk også i norske byer ofte i arv fra far til sønn eller svigersønn etter søknad og under forutsetning av at de hadde opparbeidet seg nødvendig musikalsk ferdighet. Det var også vanlig at stadsmusikantenken fikk livsvarig svennelønn etter at hennes mann, stadsmusikanten, falt fra. Det var datidens pensjon.

Christiansands Adresse Contoirs Efterretninger, nr. 13, 1798.

Christiansandske Uge-Blade, 13. desember 1781 og 21. november 1782.

Danske Kancelli, Norske Indlaeg, 4. januar 1664, Riksarkivet i Oslo.

Magistratens Arkiv. Kongebrevbok, nr. 11, 1755-1767, fol. 155b, Bergen byarkiv.

Magistratens Arkiv. Kongebrevbok, nr. 11, 1755-1767, fol. 155b, Bergen byarkiv.

Magistratens Brevkopibog, 25. oktober 1737. (Kongelig konfirmasjon 22. november 1737.) Adskillige

Bestallinger, II, Rigsarkivet i København.

Danske Kancelli, Norske Registre, 11. mai 1680, Riksarkivet i Oslo. 
Utdannelseskravet for å bli stadsmusikant i Norge var som ellers i Europa fem til seks år. Men der er eksempler fra Trondheim på at læretiden var kun tre år. ${ }^{22}$ Det kan skyldes at lærlingen hadde gode forkunnskaper. Etter endt læretid kunne musikeren kalle seg svenn. Når han da hadde fătt svennebrev, måtte han gjerne gjøre tjeneste hos en annen stadsmusikant eller mester noen år for å dyktiggjøre seg ytterligere, for eventuelt senere å bli vurdert til en ledig stadsmusikantstilling.

Stadsmusikanten var selvstendig næringsdrivende. Han skulle styre en bedrift med både svenner og lærlinger. Tjenestene var forskjellige, og stadsmusikanten måtte være meget allsidig som musiker med et tilsvarende variert repertoar for å kunne dekke de forskjellige musikkbehov i byene. Han måtte også være i besittelse av relativt store instrumentsamlinger, som bestod av så vel strenge- og tasteinstrumenter som treblåser- og messinginstrumenter som fioliner, bassvioler, cello, dulsian (forgjenger til fagotten), fagott, hobou (obo), skalmeie (forløperen for oboen), valthorn, zinke, basun, fløyte, trompet, bassetthorn (en klarinettype særlig Mozart var interessert i), klarinett, positiv, cembalo, harper og gitarer. Instrumentsamlingen var også et uttrykk for bedriftens størrelse.

I læretiden måtte en lære å spille på 5-6 forskjellige instrumenter. Skulle en få en bedrift til å lønne seg, måtte en være i stand til å ta oppdrag av forskjellig art. Stadsmusikantene skulle helst være spesialister på alle instrumenter. Den ideelle stadsmusikant skulle også kunne prima vista-spill, akkompagnere og improvisere samt være musikkpedagog. Han skulle videre være ensembleleder og kunne skaffe ønsket musikk på kort varsel. Han måtte nærmest være "altmuligmann" som skulle stå til tjeneste til alle døgnets tider. Det var ikke lett å finne den perfekte stadsmusikant med en slik profil. Verre ble det også da stillingen ble slått sammen med organistfunksjonen.

\section{Hva forte til monopolets oppløsning?}

På 1700-tallet førte samfunnsutviklingen til et økende musikkbehov. Dette underbygges ved at flere byer opprettet egne stadsmusikantstillinger. Eneretten til musikkoppvartning ble utvidet til distriktene rundt byen, og disse områdene ble ofte dekket av forpaktere til stadsmusikanten mot en viss avgift. Flere musikkoppdrag tilsa også at musikantenes allsidighet ble viktigere enn noen gang, og ved ansettelser forlangtes det prøvespill på flere instrumenter. Det ble også etter hvert vanlig med attester og dokumentasjon på gjennomgått læretid. Fra midten av århundret ble det også mer vanlig med private eller

22 Trondheims bytingsprotokoll, 22. november 1714 og Trondheim bytings domkopibok, 8. januar 1715. 
offentlige konserter i byene, og musikkselskaper ble etablert. Både stadsmusikanten, hans svenner og militærmusikere ble leid inn. Som oftest var stadsmusikanten leder for orkesteret.

Fra ca. 1750 og utover ble den kulturelle kontakten mellom Norge og resten av Europa utvidet. Frem til da hadde det hanseatiske kulturområdet vært dominerende. Nå våknet interessen for både fransk, italiensk og engelsk kulturliv. Norge fikk følgelig større påvirkning fra andre deler av Europa, og det gjaldt også i musikklivet. Samtidig levde den folkelige musikkulturen på landet. Det var flere lagdelinger i samfunnet som varierte fra distrikt til distrikt. Den norske stadsmusikantordningen fikk også sitt særpreg uavhengig av den europeiske påvirkningen.

Selv om situasjonen nå så lys ut for stadsmusikanten, begynte betydningen av det gamle privilegiet å bli mindre. Dessuten så det ut som om kvaliteten på musikernes prestasjoner etter hvert ble dårligere, da det stiltes større krav til deres musikkfaglige nivå. Nye estetiske strømninger i tiden med nye musikksjangre og synet på musikk som individuell kunst, nådde også norske forhold. Dette oppdaget tydeligvis kongen, som sendte ut reskriptet om det dårlige musikalske nivået i byene. Den kongelige resolusjonen av 1800 om sammenslåing av organist- og stadsmusikantstillingene, samt opphevelse av monopolet på landet, fikk også norske stadsmusikanter føle. Privilegiene var dermed på vei ut av Norge. Stadsmusikanten mistet noe av sitt eksistensgrunnlag og fikk følgelig større problemer med å leve av embetet. Enhver som bodde på landet, kunne etter dette benytte seg av hvilken musiker han ville uten dermed å risikere represalier av noen art. For det andre vokste kritikken mot institusjonen.

\section{Begrunnelse for en opplosning}

I litt større perspektiv kan en si at årsakene til embetets nedgang og oppløsning var de samme som i Nord-Europa. En kan finne begrunnelser så vel i den musikalske og kunstneriske utviklingen som på det idéhistoriske, sosiale og politiske og økonomiske nivå (Schwab 1978:271-281).

I den senere del av 1700-tallet kom opplysningstiden, som gjorde fornuften til rettesnor i alle livets forhold, til å prege Europa, med Voltaire og Rousseau som de mest kjente representantene. Tilliten til økt viten og kunnskap ville ifølge denne bevegelsen løse de fleste problemer. Opplysningstiden forberedte på mange måter den franske revolusjonen i 1789, som hadde til hensikt å erstatte det føydale samfunn med noe nytt under slagordet "frihet, likhet og brorskap". Den skapte en radikal omvurdering av verdisynet. Det ble et 
opprør mot tradisjonelle autoriteter og da særlig stat og kirke. Fornuften ble den nye autoriteten. Et resultat av dette var ønsket om næringsfrihet og motstand mot privilegier og laugsordninger. Demokratiske ideer brøt for alvor frem i europeisk politikk. All makt skulle tilhøre "folket", og samfunnets mål var å sikre menneskene frihet, eiendomsrett, sikkerhet og rett til å gjøre motstand mot tvang.

Kjærligheten til tonekunsten preget opplysningstidens mennesker. De hadde respekt for musikken, og så den som et nødvendig ledd i oppdragelsen. Musisering ble en fritidsbeskjeftigelse, og borgerskapet begynte å musisere. Kirkemusikken mistet noe av sin dominerende posisjon, og stadsmusikantens kirkemusikalske oppgaver fikk derved en mindre dominerende rolle. Kunstmusikken hadde dessuten en voldsom utvikling fra siste del av 1700tallet og hundre år fremover. Musikkamatørene kunne samle sammen 15-20 musikere eller flere for å oppføre både rokokko- og tidlig klassisk musikk. Det var høyst sannsynlig at stadsmusikanten og eventuelt svenner også deltok på musikkamatørenes og musikkselskapenes premisser. Flere musikalske selskaper oppstod (i Bergen i 1765, Trondheim i 1786 og Kristiansand i 1787).

\section{Nye krav til stadsmusikantene}

Flere av stadsmusikantene var dyktige og gjorde en god jobb, men mot slutten av 1700-tallet var disse musikerne, og trolig også deres musikk, i ferd med å bli umoderne. Den moderne musikken var musikkselskapenes orkesterkonserter. Musikken til Haydn, Mozart og Beethoven ble også såpass krevende å fremføre at mange stadsmusikanter ikke kunne være med. Den nye musikken og det offentlige konsertvesen gjorde krav på spesialister, virtuoser, og her holdt ikke alltid stadsmusikantene mål.

Musikkprivilegiene på landet ble av offentligheten sett på som en belastning for den moderne bonden. Det var dessuten et faktum at etterspørselen etter den type musikk som stadsmusikanten representerte, hadde gått ned, og dermed ble inntektene lavere. Musikantene hadde med andre ord vanskelig for å klare seg økonomisk. Det var for å bøte på denne situasjonen at organist- og stadsmusikantembetet ble slått sammen. Selv om hensikten var god, ble problemene ikke løst av den grunn. I norske byer med få søkere var det vanskelig å finne en musiker som behersket både dansemusikk og kirkemusikk. Kristiansand måtte dele stillingen igjen en periode for å få dekket behovet. ${ }^{23}$

23 Christianssands Stiftsavis, nr. 13, 1839 
Når de opprinnelige privilegiene ble innskrenket, prøvde den norske stadsmusikanten å finne seg nye oppgaver i musikklivet, noe det fremvoksende halvoffentlige musikklivet med musikkselskaper og offentlige konserter er ett eksempel på. På 1800-tallet står bare stadsmusikantens danseoppdrag igjen. Da forsøkte han å utvide sin virksomhet ytterligere på andre områder. Det kunne være å undervise flere musikkelever eller å ha andre utenommusikalske oppdrag.

\section{De nye handelslovene}

Da de nye handelslovene kom i slutten av 1830-årene, hvor næringsdrivende mistet monopol og privilegier, ble musikken en fri næring. Stadsmusikanten kunne spesialisere seg på dansemusikk, men også her fikk han konkurranse fra frie danseensembler som for eksempel det tyske orkesteret Harz-Verein, som kom til Norge på turné i 1840 (Michelsen 1979:293294). Det var nå likevel de organiserte militær-musikkorpsene som i løpet av 1800-tallet overtok det meste av de opprinnelige pliktene stadsmusikantene håndhevet på 1700-tallet. Dette gjaldt musikk både til spesielle anledninger, underholdning, dans og ikke minst til offentlige høytider som for eksempel 17. mai. Å være militærkorpsinstruktør var på mange måter en fortsettelse av det mangeårige stadsmusikantvervet, som etter hvert ble overflødig $i$ sin gamle form. Kravet om virtuose ferdigheter på ett instrument sammen med kravet om å forsyne innbyggerne med den nyeste dansemusikk og annen bruksmusikk, sprengte til slutt stadsmusikantembetet.

\section{Sammenligning av den europeiske og den norske stadmusikantordningen}

Dersom en kan si at den norske stadsmusikantordningen var en forenklet utgave av den danske, kan denne forskjellen forsterkes fra en europeisk synsvinkel. Det var et faktum at den norske stadsmusikantvarianten hadde et dårligere utgangspunkt både når det gjaldt byenes størrelse, økonomi, musikerstatus og ikke minst byenes satsing, for å nevne noe.

Alt dette var en nødvendig forutsetning for en vellykket stadsmusikantordning.

De europeiske stadsmusikanter, og spesielt de tyske, må kunne sies å ha vært så godt organisert og at de var et eksempel for andre land. Dette gav da også musikerne en bedre status enn de norske. I kampen mot fuskerne hadde også de tyske laugene metoder som ikke ble gjennomført i Norge (Altenburg 1973:169). De norske stadsmusikantene var da heller ikke organiserte i laug.

Trass i en forenkling av den norske stadsmusikantvarianten hadde flertallet av tilsatte stadsmusikanter tysk eller dansk opphav. Hva kunne det skyldes? 
I utgangspunktet skulle en tro at norske stillinger helst ble besatt av norske musikere, men det betinget at det var nok kvalifiserte musikere å velge mellom. Når søkermassen til norske stillinger var så liten som tilfellet var, kan det normalt oppfattes som om stillingene var lite attraktive. De norske forholdene var nok kjent for aktuelle søkere både fra inn- og utland, og i perioder med familieovertakelse var stillingene besatt lenge før de egentlig var ledige. Enkelte potensielle søkere fikk med andre ord ikke anledning til å søke, mens andre ikke var interessert på grunn av forholdene.

Når så mange danske og tyske musikere likevel ble stadsmusikanter i norske byer, må de nødvendigvis ha sett på forholdene i Norge som en utfordring, ellers hadde de vel ikke søkt. Dessuten var nok konkurransen i deres hjemland rimelig stor. $\AA$ være norsk stadsmusikant var også bedre enn en fremtid som svenn i sitt hjemland. Erfaring som stadsmusikant hadde dessuten betydning for eventuelle senere søknader til mer attraktive stillinger. Merkelig nok var det få som benyttet seg av muligheten til å skifte stilling. Stadsmusikantstillinger i Danmark-Norge var i prinsippet livsvarige. Når noen få stadsmusikanter i norske byer sa opp stillingene frivillig, skyldtes det i all hovedsak de økonomiske forholdene.

\section{Hva slags betydning hadde da stadsmusikantene egentlig for Norge og norsk musikkliv?}

For det første var stadsmusikantenes formidlerrolle av positiv betydning for virksomheten $\mathrm{i}$ norske byer, og ved embetets utbredelse må en anta at et stadig bredere lag av både byborgere og bønder fikk kontakt med en mer og mer felles europeisk musikk. Trass i disse utenlandske påvirkningene har noen norske bønder hatt en egen evne til å ta vare på egne, gamle tradisjoner og utviklet dem. For det andre medførte stadsmusikantordningen at det meste av landet ble dekket med profesjonell musikkaktivitet, og det var i seg selv imponerende. For det tredje brakte først og fremst utenlandske musikere med seg tradisjoner og musikk fra kontinentet, der det ble stilt krav til dyktighet. Det var med på å heve nivået også blant norske musikere. I enkelte miljøer, spesielt på bygdene, ble stadsmusikantens musikk oppfattet som et fremmedelement. Derfor foretrakk mange å heller engasjere lokale spillemenn eller fuskere i stedet for den privilegerte stadsmusikanten og/eller hans forpaktere med de konsekvenser det kunne få.

Stadsmusikantinstitusjonen tilpasset seg i stor grad de lokale, norske forhold. Selv om det var betydelig enklere forhold enn i mange andre europeiske land, ble stadsmusikantenes store entusiasme og faglige dyktighet viktige årsaker til at embetet i Norge ble opprettholdt $\mathrm{i}$ ca. 250 år. 


\section{Litteratur}

Altenburg, D. (1973). Untersuchungen zur Geschichte der Trompet eim Zeitalter der Clarinblaskunst (15001800), bd.1, Regensburg.

Andersson, G. (1994). ”Der Ostseeraum als Musiklandschaft. Musiker-Musikinstitutionen-Repertoires im 17. und. 18. Jahrhundert”, i: Klaus Wolfgang Niemöller og Helmut Loos (red.), Die musik der Deutschen im Osten und ihre Wechselwirkung mit den Nachbarn (Deutsche musikk im Osten 6), Bonn.

Budde, J.F. (1842). Ueber Rechtlosigkeit, Ehrlosigkeit und Echtlosigkeit, Bonn.

Christensen, V. (1916). "Stadsmusikanten", i Historiske meddelelser om København, hefte 5, København.

Dahlback, K. (1956). ’Rokokkomusikk i trøndersk miljø. Johan Henrik Berlin (1741-1807)”, i Norsk Musikkgransknings Årbok 1954--1955, Oslo.

Dobitschen, H.L (1949). ’Ein unbekannter Schüler Seb. Bach”, i Bach-Jahrbuch 1949-50, Leipzig.

Feldbæk, O. (1991). Dansk identitetshistorie, 1, København.

Gerber, E.L. (1977). "Johan Daniel Berlin”, i Historisch-Biographisches Lexikon der Tonkünstler,1790-1792, bd.1, Graz. Westfälische-Wilhelms-Universität, Münster.

Grimberg, C. (red.) (1960). ”Den tyske Hansa”, i Menneskenes liv og historie, bd. 9, Oslo.

Grinde, Nils (1971). "Musikklivet i seinrenessanse og barokk", i Norsk Musikkhistorie, Oslo-Bergen-Tromsø.

Græsvold, H.M. (1976). Lorents Nicolai Berg og hans lærebok 'Den første prøve for begyndere udi instrumentalkunsten' ”, i Studia musicalogica nervegica, nr. 2, Oslo.Haensel, U. (1970). Musikgeschichte Kiels im Mittelalter, Kiel.

Helle, K. (red.) (1995). Bergen bys historie, bd. 1, 2. opplag, Bergen.

Hernes, A. (1952). Impuls og tradisjon i norsk musikk 1500-1800, Oslo.

Holberg, L. (1943). Memoire. Kommentert udgave ved F.J. Billeskov Jansen, Det Schønbergske Forlag København.

Huldt-Nystrøm, H. (1977). ”Musikklivet i Trondheim på 1600-tallet”, i Trondhjemske Samlinger, bd. 10, hefte 2, Trondheim.

Huldt-Nystrøm, H. (1977). "Fra musikklivet i Trondheim omkring år 1800. Stadsmusikant Peter Eberg”, i

Hampus Huldt-Nystrøm, Haakon Odd Christensen, Knut Bergersen og Per Hjort Albretsen (red.). Ringve museums 25år. Festskrift til jubileet. Ringve Museums Skrifter, bd. III, Trondheim.

Jespersen, K.J.V. (1989). Danmarks historie, Tiden 1648-1730, København.

Keyser, R. og Munch, P.A. (1848). Norges gamle love, bd. 2, Christiania.

Kortsen, Bjarne (1984. The Music of Johan Daniel Berlin, 1714-87, Bergen.

Koudal, J.H. (2000). For borger og bønder. Stadsmusikantvaesenet i Danmark 1660-1800, København.

Langwill, L.G. (1952). "The Waits. A Short Historical Study", i Music Book, Volume VII of Hinrichsen's Musical Year-Book,London.

Lundeby, E. (1974). "Trondheim”, i Aschehougs konversasjonsleksikon, bd.19, Oslo.

Mendel, H. (1878). "Stadtmusicus", i Musikalisches Conversations-Lexicon, bd. 9, Berlin.

Michelsen, K. (red.) (1979). ”Harz-verein ”, i Cappelens musikkleksikon, bd. 3, Oslo. 
Michelsen; K. (red.) (1987). Johan Daniel Berlin 1714-1787. Universalgeniet i Ttrondheim, i Ringve Museums Skrifter IV, Trondheim.

Nedrebø, Y. (1992). "Fra Scandinavias største by til strilane sin hovedstad. Folketalsutvikling og folkegrupper i Bergen 1600-1900" (Kompendium), Statsarkivet i Bergen.

Nicolaysen, N. (1878). Bergens Borgerbog for 1535-1751, Christiania.

Norlind, T. (1940). "Musiker och lekare under medeltiden i Sverige”, i Svensk tidsskrift för musikforskning, 22. årgang, Stockholm.

Olrik, A. (1886). "Middelalderens vandrende spillemænd i Norden og deres Visesang”, i Opuscula philologica, philologiske Arbejder udg. Af det philologisk-historiske Samfund, København.

Reznicek, L. (1975). Edvard Grieg og tjekkisk kultur, Oslo, Biblioscandia, 1975. Boken har ingen sidetall.

Schiörring, N. (1977) "Tårnblåsere og Stadsmusikanter”, i Musikkens Historie i Danmark, bd. 1. København 1977.

Schiørring, N. (red.) (1977-78). Musikkens Historie i Danmark, bd.1, s. 65-80.

Schwab, H.W. (1982) Die Anfänge des weltlichen Berufsmusikantentums in der mittelalterlichen Stadt. Studie zu einer Berufs- und Sozialgeschichte des Stadtmusikantetums, Kasses-Basel-London.

Schwab, H.W. (1989). "Zur Struktur der 'Musikkultur des Ostseeraumes' wärend des 17. Jahrhunderts", i SvenOlof Lindquist (red.) Economy and Culture in the Baltic 1650-1700, Visby 1989, s. 141-160.

Schwab, H.W. (1997). "Zur Representänz der Städte durch ihre Musiker", i Julia-K. Bütke og Thomas Riis (red.). Studien zur geschichte des Ostseeraumes II, Die Städte des Ostseeraumes als Vermittler von Kultur 1240-1720, Odense 1997.

Schwab, H.W. (1978). "Krise und Auflösung des Stadtmusikantentums", i Uwe Haensel (red.). Beitrage zur Musikgeschichte Nordeuropas. Kurt Gudewill zum 65. Geburtstag, Wolffenbüttel 1978:271-282. Christianssands Stiftsavis (1839). Nr. 13,

Seip, D.A. og Wallén, P.E. (1965). "Leikarar”, i Georg Rona (red.). Kulturhistorisk leksikon for nordisk middelalder, bd.10, København.

Selvik, R.M. (2005). ”Kjendere og Liebhabere”. Musikere og musikkliv i Bergen ca. 1750-1830, Trondheim.

Sivertsen, H. (1975). "Det Trondhjemske Musikalske Selskab av 1786", i Ringve Museums skrifter, bd. I, Trondheim

Stakkeland, A. (2011). Det privilegerte musikksystemet, Universitetet i Agder.

Steen, S. (1941). Kristiansands historie 1641-1814, Oslo 1941.

Troels-Lund, T. (1939). Dagligliv i Norden i det sekstende århundre, 9-11 bok, Oslo 1939.

Volle, B. (1979). Om stadsmusikantene i Bergen 1620-1759. Hovedoppgave ved Universitetet i Oslo.

Vollsnes, A.O. (1989). "Stadsmusikanter-forpaktere- og fuskere”, i Rapport från en forskerkonferens i Arvika 30-31 januari 1989, Göteborg. (Fra skriftserien ”Musikk i Värmland - I).

Vollsnes, A.O. (red.) (2001). Norges musikkhistorie, bd. I, Oslo.

Wiesener, A.M. (1943). "Om stadsmusikantene i Bergen”, i Bergens historiske forenings skrifter, nr. 49, Bergen.

Zak, S. (1979). Musik als "Ehr und Zier”, im mittelalterlichen Reich. Studien zur Musik im höfischen Leben, Recht und Zeremoniel, Neuss. 


\section{Arkiv og arkivale bøker}

Danske Kancelli, Norske Registre, 1637-1642, folie 215b-217b, Riksarkivet i Oslo.

Fogtman, L. et al. Kongelige Rescripter, Resolutioner og Kollegialbreve for Danmark og Norge

1660-1848, 1-49, København 1786-1854, nr. 2, s. 9.

Nielsen, O.: Kjøbenhavns Diplomatarium. Samling av Dokumenter, Breve og andre Kilder til Oplysning om Kjøbenhavns aeldre Forhold før 1728, nr. 8, København 1872-1887.

Fogtman, L. et al. Kongelige Rescripter, Resolutioner og Kollegialbreve for Danmark og Norge 1660-1848, 149, 6. del, 2. bind, s. 302, Rigsarkivet i København.

Magistratens Copibog for Kristiansand, nr. 25, s. 685-686.

Kongelige Rescripter, Resolutioner og Collegial-breve, bd. 4, 1797-1813, 29. mai 1800, Christiania 1845.

Kong Christian den Femtes Forordninger og Aabne Breve 1699-1700, København uten årstall, s. 4f.

Danske Kancelli, Norske Indloeg, 4. januar 1664, Riksarkivet i Oslo.

Magistratens Arkiv. Kongebrevbok, nr. 11, 1755-1767, fol. 155b, Bergen byarkiv Loc.cit.

Magistratens Brevkopibog, 25. oktober 1737. (Kongelig konfirmasjon 22. november 1737.) Adskillige

Bestallinger, II, Rigsarkivet i København.

Danske Kancelli, Norske Registre, 11. mai 1680, Riksarkivet i Oslo.

Trondheims bytingsprotokoll, 22. november 1714 og Trondheim bytings domkopibok, 8. januar 1715.

Wessel-Berg, Fr. Aug.: Kongelige Rescripter, Resolutioner og Collegial-Breve for Norge i tidsrommet 1660-1813, bd. 1, Christiania 1814-47, s. 58.

\section{Aviser og blader}

Christiansandske Uge-Blade, 13. desember 1781 og 21. november 1782.

Christiansands Adresse Contoirs Efterretninger (1798). nr. 13.

Christiansand Stiftsavis (1847), nr. 34.

Rojahn, Ferdinand (1892). "Historisk oversikt over Musikforholdene i Christianssand ", Bilag til Christianssands Tidende

\section{Notemateriell, en oversikt:}

\section{Saxild, Otto:}

- $\quad$ Vals fra omkring 1791-92.

\section{Grose, Michael Ehregott:}

- 24 Lieder von guten Dichtern, 1780.

- 6 Sonates faciles pour le Clavecin au Pianoforte, 1785.

- Ved Henriette Katzensteins Grav, 1788.

- Baronesse von Mestmachers Vers. Maurenbrechers Abschieds-Szene bei dem Sterbebett von Frau von Ross, 1789.

- $\quad$ Samling av lette Claveer, Harpe og Syngestykker for Liebhabere og Begyndere.

- Hft. 1-4, 1791. 
- Cantate opført i det kgl. musikalske Avcademi i Anledning af kronprinsessens Nedkomst, 1792, klaveruttog 1793.

- Sang i Anledning af Christiansborgs Brand den 26. Februar 1794, klaveruttog 1794.

Berlin, Johan Daniel:

- $\quad$ Fiolinkonsert i A-dur

- Sinfonia a 5 i D-dur for strykere og zinke.

- $\quad$ Sinfonia a 6 i D-dur for strykere, fløyte og klarinetter.

- $\quad$ Sinfonia a 8 i D-dur for strykere og klarinetter.

- 6 menuetter for Cembalo.

- Sonatina for Cembalo.

- Allegro for Cembalo.

- Aria for Cembalo

\section{Schediwy, Ferdinand Giovanni:}

- Choraler afsjunget i Bergen Domkirke den 5te Novbr. 1873.

- $\quad$ Syngespillet Den første Jøde.

- $\quad$ Syngespillet Når Kjærligheden Kjølnes, 1844.

- Scenemusikk til skuespillet Gildet på Solhaug av Henrik Ibsen.

- Scenemusikk til Olaf Liljekrans av Henrik Ibsen.

- Udvalg av Choralmelodier til Guldbergs, Evangelisk-christelig og Kingos Psalmebog, udsatte for Psalmodicon.

- Skole-Sangbog indeholdende 30 trestemmige Sange.

- $\quad$ Kantate. På det norske Universitets femtiaarige stiftelsesdag den 2den Septbr. 1861.

- Til Kvinden. Sang fra F.G. Schediwy d.16de Juni 1863 til F.W. Thoschlag.

- 75 av de mest brugelige Koralmelodier, indrettede for 3 Børnestemmer til Brug i Skolen og hjemmet.

- Trende Valser for pianoforte tilegnet det Bergenske Musikelskede Publicum.

- 6 Sange for fire Mandstemmer af Josef Panny, udgivne av Schediwy.

- Norges Herlighed. Norsk Nasjonalsang av biskop J.N. Brun. Melodien variert af Joseph Panny og udsat for Piano av Schediwy.

- Nei. Vaudeville av J.L. Heiberg. Musikken arrangert og componeret af F.G. Schediwy.

- $\quad$ Samling af nye og yndede Dandse og Marscher et $\mathrm{C}$ tra for Piano Forte. 